\title{
The Relational Hypotheses of Earth's Societies
}

\author{
Rinaldo C Michelini Di San Martino* \\ Dimec - Università Di Genova, Italy \\ *Corresponding author: Rinaldo C Michelini Di San Martino, Dimec - Università Di Genova, Italy
}

\section{ARTICLE INFO}

Received: November 05, 2021

Published: 幽 November 19, 2021

Citation: Rinaldo C Michelini Di San Martino. The Relational Hypotheses of Earth's Societies. Biomed J Sci \& Tech Res 40(1)2021. BJSTR. MS.ID.006403.

Keywords: Relational Hypotheses; Interpersonal Ranges: Political Business and Individual; Bottom-Up Construal: Communication Teamwork and Governance; Wealth Sources and Relational Modes; Altruism and Sustainability

\begin{abstract}
On earth, the 〈biology> entails the ‘growth〉 process, and the «cognition〉 involves the knowledge 〈progress〉. The 〈growth〉 describes material lifecycles, with births and deaths, maybe, bringing to expansion of the life beings; the «progress > tells about forward awareness and understanding, opposed to regress or intellect decrease, as the figure is symbolic appraisal of the human deployments. The material backgrounds and 〈biology> typify by <entropy> and all our narrations show a future decay, towards the end of the self-ruling civilisation. In parallel, the intellectual framings and (cognition» settings characterise by the symbolic processing of ideas, concepts, theories or interpretations of events or items, occurring around the human beings. The latter picture deals with the abstract thoughts, the careful intelligence, the sound rationality, the clever selection and so on, namely, the efficient decision-making of the men's society on the earth. The paper addresses how the «mind develops on interpersonal education and defines the relational traits, as fit support of the proper human behaviour, even while we expect approaching critical breakthroughs.
\end{abstract}

\section{Introduction}

The earth's society builds, supported by «men's inventions», with relevant abstract features and intellectual spins, adding personal, communal and sovereign frame standards. The extant «nations〉 distinguish by idioms and governments, enjoying entitled administration and ruling layouts. These characterise the «civilisation〉 idiosyncrasy, assuming peculiar entrustments, such as:

a) Divine running: the material world has governance in upper godlike reality

b) Natural backdrop: the universe has inner ruling, due to cosmos' regularity;

c) Interpersonal assignment: the collective steering refers to endorsed edicts.

The divine and the natural 〈laws〉 are total truths, with upper or inner worth, out of man's span; they offer consistent 〈faiths〉: the former, once transcendence is recognised proposition; the latter, if 〈information` immanence qualifies the material reality. The human 〈laws〉 are contingent forms, with provisional meanings, linked to current contexts. The 〈faiths〉 in 〈total dualism〉 or in 〈qualified monism» are a priori guesses; they deserve a posteriori justifying trials, weather theory foundation is expected. The transcendence cannot enjoy direct perception; the cogent immanence admits the «matter/information» coherence, vindicating the cosmos' physics. The third sample allocation has only posteriori evidence, limiting the build-up of 〈knowledge〉 and «science〉 to what learned and systematised, having agreement of the fellow researchers.

We do not deal with total laws; we just acknowledge provisional conjectures [1-5]. In the study, the third entrustment is usual pick, to depict the earth's society, with the account of how the humankind organises the «civilisation〉 questions. The analyses consider the 〈relational hypotheses», which explore the personal teaching/ learning, copying/emulation, training/appraisal, etc., to implement the series of software/hardware outfits of the human peoples [611]: 
- Community organisation: internal infrastructures, for balanced private/public running;

- Legality frames: political substructures, for civil behaviours and communal enactments.

- Authority schemes: autonomy and sovereignty figures, for independent administrations;

- Nation-state operation layouts, to achieve comparative civic and executive performance;

- Mutual establishments: economic substructures, for supply chains and trade provision;

- $\quad$ Productive setups: business, agrarian and industry devices, for goods and stocks making;

- Conversion and restructuring plans: technical and management changes, for throughput. The earth's society is conservative and intellectual invention, imagining complex sets of mental surveys, to deal with multiple substructures and critical establishments. These software/hardware setups concern the regulation of communities, through internal rules and external safeguards. The idea of structured assemblies brings to rubrics, directives, duties and obligations, all abstract signs, further than material pieces. The intellectual (or spiritual) cues, in keeping with the three starting allocations, have traditionally entailed typifying situations:

- Divine 〈laws», when «spirit» has transcendent connotation, to grant absolute rate;

- Natural 〈laws〉, if 〈matter/information» joining assures kami-driven total worthiness;

- Human 〈laws〉, if 〈qualified agreement〉 leads to shared sanctioning of given edicts.

With the molecular biology, genome and its information merge: we only need decoding jobs; the natural 〈laws〉 involve encoded deterministic issues and 〈spirit〉 degrades to animism, without upper independent steering. With the human intellect, «spirit〉 converts in mind activity, to handle concepts, imagined and shared as community prerequisite. The survey of the software/hardware setups leading the earth's society, hereafter, analyses the above listed main formats [12-16].

\section{The Core Formats of Earth's Society}

The earth's society has anthropoid centering, due to interpersonal talents, i.e., 〈idiom〉, 〈market〉 and 〈law〉, Figure 1, based on mental activity, once the human «mind > forms by learning and training. In some formal approaches, the «mind sormat has absolute worth, assigning divine/natural origin to the extant 〈legality〉 frames. These happen as odd 〈beliefs〉, but we have already left total trusts, for contingent guesses, when dealing with the human 〈law frames [17-21]. The earth extant peoples distinguish by idioms and governments, enjoying joint political and economic layouts. The compositions appear native arrangements, with recent worries on financial flops due to lop-sided split-sovereignty and on wealth inequality of the citizens at the nation and at the world ranges. The hindrances are summarised by assessed facts, with well-known essential hints. Yet, the initial discussion of the current formats permits grasping how the earth's society develops on «relational〉 skills.

\section{EART'S SOCIETY: THE ORGANISATION OF HUMAM ASSEMBLIES WITH UNNER LEGALITY AND OUTER TRATIES SETUPS: COMMUNICATION/TRADE/AUTHORITY TOOLS: LANGUAGE MARKET AND POLITICAL OPTIONS FORMATS: (TOTAL) FRAMES: DIVINE/NATURAL; (CONTINGENT) FRAME: INTERPERSONAL AGREEMENTS}

Figure 1: The earth's society: anthropoid setups.

\section{Community Organisation}

The earth is negligible planet in the universe, where life courses occur, ensued by living beings with brain-to-mind talent, i.e., intellect. The combined oddities establish complex issues [22-27], by:

- Agentive trails: gene evolution, ethnic greediness, active rivalry, clan solidarity;

- Relational trails: meme fruition, emulation/simulation abilities, wise rationality.

The biology has standard effects: gene evolution` creates many living species, aiming at better-adapted samples, (Figure 2). The «mimicry» requires self-awareness, spotting construct as identifying traits. The cognizance courses occur, when mutual completion establishes by personal education with formal gears. The earth's relational model, typically, avails of three intellection mechanisms:

- Communication tools: the population language and the clan dialect;

- Market tools: the domestic supply and budget balancing by trading;

- Governance tools: the country's autonomy via sovereign authority. 


\section{EARTH'S SOCIETY MODEL: THE INTERPERSONAL'TEACHING/LEARNIING OF CULTURE/ETHICS DEPOYMENTS MOLECULAR BIOLOGY: GENE EVOLUTION, WITH THE LIFE FORMS' ADAPTATION TO THE CURRENT SURROUNDS JOINT COGNIZANCE: MEME FRUITION, WITH THE KNOWLEDGE (AND SCIENCES) GRADUAL ESTABLISHMENTS}

Figure 2: Hardwae/software formats of the earth's society.

The «selfish gene» affects the relational model, bringing about «closed societies» in competition, qualified by idiom and sovereign. The rationality> can suggest switching to «altruist memes, leading to «open societies», at global village consistency. Nonetheless, the «closed society〉 is classic choice: we distinguish citizens from foreigners; the split-sovereignty is coherent standard, to deal with lots of independent «nation-states». The sovereignty happens having citizens' origin, via (Constitution〉, which establishes the limits of the government's acts: the law authenticity resides in citizens; the government has delegated relative power. The «people sovereignty> appeared in history periods, when total readings, were no more plausible. Indeed, the authenticity, along centuries, undergoes changes, entailing divine or racial investitures, say, godlike or ethnic worth of the «nation», implying sharp communities' endpoints.

\section{Legality Frames}

The relational interactions involve mimicry skills, each individual being capable to figure out his intellectual duplication. The meme fruition entails the said mechanisms, at three layers:

a) Personal, to learn, practice and transmit the communication idiom and knowledge;

b) Domestic, to manage the family/home sources and accounts by shared marketing;

c) Civic, to fulfil the tribe/nation's activities and duties, in respect of the indorsed acts.

The three spheres have contingent worh, linked to the timely earth's society settings. The inner one is interpersonal: it establishes the «mind), with the abstraction talent to objectivise acts, goals feelings and layouts. The next one deals with «open societies», soon, taking out the linked «closed society), into which organising effective legal frames, for the operation political structures [2832]. The recent political spheres follow split-sovereignty models, in the «capitalism», with separate ruling than wealth. The income inequality is actual concern; the 〈fortune inequality is intricate query: the saffluence of individuals says that the accumulation, due to their activity, is possible, with allowed transmission (within a family); the sassets of enterprises mean that the build-up, due to the tied activity, is qualifying result of the organised business.

The 〈accruals〉 build up as «wealth expansion〉 or 〈growth», leading to improved opulences. The outcome is measured by «money〉 or, using an established designation, by «financial capital», under 〈sovereign〉 ruling. The «wealth〉 of nations, besides state property (Latin 〈demanium〉), assembles private ownership with (public) Treasury (UK Exchequer): the fiscal income links to the gross national product, GNP. If the government expenditures exceed the revenue from taxes, the Treasury shall get into debt, issuing bonds or other sureties. The country's riches are marginal opulence; the fiscal earnings are usual treasury means, managed as (financial capital), (Figure 3), by legal features

\section{NATION-STATE INDEPENDENCE: THE SPLIT-SOVEREIGNTY POLITICAL INSTYTUTIONS PRIVATE LAW: THE RULES REGULATING THE CURRENT RELATIONSHIPSS BETWEN THE SINGLE CITIZENS PUBLIC LAW: THE RULES AFFECTING THE INDIVIDUAL CITIZENS, UNDER THE EXTANT GOVERNMENT}

Figure 3: The legality enacted by sovereign natio-states.

\section{Authority Schemes}

The personal/domestic/civic layers allow sovereign political setups, as if the hierarchy aimed and exclusive performance distinguishes the nation state's spheres. The enabled effectiveness is competition option and the operation layouts distinguish due to the civic and executive planning. The recent events oppose 〈communism〉 to «capitalism», i.e., state-ruled vs. private-owned wealth. In any case, the «nation-state〉 is basic reference, enjoying 〈split-sovereignty〉 and 〈democracy〉 say, the «people authority»,
(Figure 4), with contingent worthiness [33-38]. The self-ruling governance gives political and economic autonomy. In the picture, the 〈income〉 allows finance transactions; «wealth links to the «stored capital», with money worth: individuals' ownerships, companies' assets and governmental treasury, if we follow the 〈capitalism», with private vs. public ownership. In the «communism» reading, all is communal, under the central nomenclature steering; for a while, the XX century> fancied hinting the community track to be superior feat. 


\section{COUNTRY'S AUTONOMY MODELST: THE SPLIT-SOVEREIGNTY LEADS TO SELF-RULING GOVERNANCE TOTAL TRUTHS: (DIVINE〉 OR 〈NATURAL) SETUPS OFFER HINTS ABOUT HIERARCHY GOVERNMENT LAYOUTS CONTINGENT OPTIONS: 〈HUMAN〉 ARRANGEMENTS ALLOW COMMUNISM OR CAPITALISM AUTHORITIES}

Figure 4: The administation independence allows hierarchy authority.

The millennium starts, showing self-disintegration of the conjured enhanced frame. The XXI century 〈capitalism〉 is hybrid setup, with global urges: 〈communication〉, <economy and 〈ecology〉. The sglobal communication` provides plenty options, with private profits (known list) and public advantage (including control of citizens' interactions and messages!). The (global economy> means that the split-sovereignty> is non-sense, if the financial independence does not exist anymore: the biasing monetary guiles (Keynes' manoeuvers, currency devaluations, etc.) are two-edge tricks, untying ruins. The (global ecology> is XXI century drawback, leading to downfalls, if out of sustainability plans. These brief cues show that hybrid «capitalism», also, needs revisions.

\section{Teamwork Patterns}

The human «culture/ethics〉 syntheses distinguish due to cooperative accomplishments, leading to combine plans, aimed at useful results, with social or technical traits, (Figure 5). The previous points offer cues the authenticity and accounting backings. The supply chain speciality requests, as well, front-end practical material transformations, to obtain useful products. These substructures have processing and economic worth, as the interpersonal acts enable fit issues. The relational options, language, trade and legality, enjoy combined gene and meme trails. The divine spirit is old spur to intellect. In the Darwinism, the gene evolution offers suggestions. Further hints need be added, to summarise the state of the art on the subject, to show the overall complexity of the topics [39-43].

In modern ages, the relational structures stabilise at three levels:

a) The outer political, with the «nation-state invention and the related legality;

b) The middle domestic, with mutual civic establishments and trade provisions;

c) The inner subjective, with agreements on worthy «private> and 〈public roles.

\section{PROVISIONS AND DELIVERIES: RELATIONAL CONSTRUAL, TO RUN CIVIC ORDERS \& PROCESSING DUTIES SOCIAL TRAITS: (POLITICA) AND (ECONOMIC) SETUPS, ENJOYING EFFECTIVE CIVIC ORGANISATIONAL LAYOUTS TECHNICAL TRAITS: 〈PRODUCTIVE PROCESS〉 INVENTION, TO ALLOW AUTOMATIC THROUGHPUT AND CONTROL}

Figure 5: Interpersonal deeds for supply chauns.

The arrangements are men's invention, moving from idioms for shared grasp, market for joint business and authority for common officialdom. The red tape is vital, only if parallel actors work. The trade relevant, especially after agrarian/industrial revolutions, with mass-production. Yet, the relational ability establishes with the spoken/written languages, which allow deep understanding and multiple appreciation. The built 〈knowledge〉 allows sophisticated novelties:

d) The mass-outputs, through the (notably agrarian and industrial) revolutions;

e) The artificial life/intelligence yields, by modulating the cognitive revolution.

The collaborative teamwork is meme fruition chance, stopping gene selfishness, as 〈rationality〉 shows possible alternatives, towards betterments. The revolutions are bets, with contingent value; a posteriori, only, we become aware of profits. The cooperative thinking is further fulfilment, with ways to the intellectual conception of useful operations and structures.

\section{Productive Outcomes}

The work-Organisation revolutions implement software/ hardware setups, with multiple objects and relevant improvements. The «inventions» cover mental deployments, fully building intellectual construal, with interpersonal teamwork achievements. Example issues cover:

a) Social enhancements, since the efficiency directly affects the results' spheres;

b) Legal structures, with creation of «nation-state> or other analogous institutes; 
c) Political ideas, connecting the domestic assemblies with civic and global links;

d) Technical options, discovering synthetic rulings, to justify the expected issues.

The work-organisation deeply affects the agrarian/industrial upheavals, when the new orders, with independent administrations of split-sovereign countries establish. The outcome brings to the competition of parallel «nation-states», at unlike 〈progress〉 phases. The 〈revolutions〉 are technical mark, showing the society's effectiveness of the current local civilization. The sproductivity is talk unknown in wilderness; it becomes critical comparative figure. The 〈progress', however, is relative quantity: the choice can have preferences, but cannot be sure of an upgrading; our example issues are mind's ideas, not cosmos' information [44-49] (Figure 6).

\section{TECHNOLOGY INNOVATION: THE WORK-ORGANISATION, VIA YERARCHIC PLANNING AND GOVERNANCE AGRARIAN REVOLUTION: THE ARTIFICIAL PLANNING AND PERFORMING (BIOLOGY) FORMATS AND PROCESSES INDUSTRIAL REVOLUTION: THE HUMAN 〈WORK-ORGANISATION) VIA AUTOMATION AND ARTIFICIAL (ENERGY)}

Figure 6: Organisation/mechanisation of the productive setups.

\section{Operation Workings}

On our negligible planet, the earth's society has anthropoid driver, because the intellect limits to men. The 〈progress is clever choice: 〈obvious〉, if 〈possible〉: the 〈productivity〉 is magic aim; the «entropy» shows that limits exist. We might only inspire to anthropic doctrines and we may look at iterating as much as possible the 〈ife〉 and «intelligence〉 singularities via artificial doubles, (Figure 7). The analyses are, possibly, fantastic and, just, used to provide hints. The «intellect» or, perhaps, the «spirit» looks at the «conversion» towards artificial life/intelligence and then, at 〈restructuring〉 the originally planned «technical and management changes». The images lead to assemble:

a) The relational skill exploration: idiom/symbol, market/trade and authority/law;

b) The matter/knowledge forward/backward «conversion» of engineering chores;

c) The design synthesis, effecting natural provisions through artificial replications.

\section{KNOWLEDGE REVOLUTION: THE ARTIFICIAL PROCEDURES, TO ENHANCE THE INTANGIBLE PROCESSNG ARTIFICIAL LIFE: SUPPORTING ENHANCED REVERSIBILITY FOR FIT (RECOVERY) AND (RECYCLING) OPERATIONS ARTIFICIAL INTELLIGENCE: PROVIDING SUITED INTANGIBLE 〈ADDITIONS〉 OR 〈ALTERNATIVES〉 OPPORTUNITIES}

Figure 7: Anthropoid emulation of technical operation processes.

The men's society develops because of the 〈relational〉 competences, fashioned and specialized by coaching, tutoring and training the children. The preliminary civilization enjoys substantial lack of restrictions, with loosely interacting tribes, easily moving to set-apart locations. The history age tells about countries and sovereigns in competition, i.e., wars, winners and losers. The periods-to -come show the earth approaching a common global village, in which we need cohabiting, keeping the safeguard of goods and objects we have to share. The future deploys with new challenges: the saving, cutback and remediation are investigated by moving many material processes, to cognitive additions and transformations on intangibles, to minimize the entropy contexts [50-55].

\section{The Earth's Society Economy/Ecology Defies}

The 〈global〉 defies are curious outcomes, with series of side- facts, making difficult to excerpt some simple remedy, due to the cross-link of situations. The present analyses address the fact to deal with human communities and look at explaining the «civilization〉 as direct organized outcome of intelligent) operators in their current conditions. The picture entails the useful earth's sources or «natural capital» and the «thinking heads〉, i.e., the operative skills of men or «human capital, based on agentive and rational talents, to create artificial results. The conventional assessments is rooted in «money〉 or «financial capital», synthetic trick, dressing balanced bargains, once adding up the (technical capitals, to include men's invented procedures and contrivances, (Figure 8). Curbing fact is today the 〈natural capital〉: the (growth〉 is 〈transformation-based〉; the «entropy> presumes decay and the «wealth expansion〉 cannot be endless, but the negative effects will propagate the global village over. The 〈global defies, simply, show the end of «our human cycle〉 [56-61]. 


\section{RELATIONAL MODES: CULTURE/ETHICS CONSTRUAL, FROM INTERPERSONAL EDUCATION/SWOTTING 1) MATERIAL CAPITAL: THE TANGIBLES - 2) HUMAN CAPITAL: THE WORKFORCE \& MANAGEMENT OPERATIONS 3) TECHNICAL CAPITAL: THE KNOW-HOW - 4) FINANCIAL CAPITAL: THE MONEY \& COMMERCIAL PRACTICES}

Figure 8: The basic «capitals» of the relational modes.

The 〈relational modes〉 amplify the reality, adding images, links and qualities, i.e., symbolic cues fulfilling, however, the characterisation of the pending occurrences. The multiple accounts, dealing with idiom (to talk), market (to trade) and legality (to enact), show that these modes build on joint interactions, or that the «human mind starts forming, when cross-faced and coached. Linkage and education reflect on the basic 〈capitals〉, giving evidence to some meanings and symbols. We recall example hints, to manage the said multiple accounts, in view of future challenges.

\section{Relational Modes}

The «uman progress` is open query. The financial packing (individuals' ownerships, companies' assets and governmental treasury) are risky blurs, if just rooted in the «contrived» sovereignty of the «nation-states». The dominance gives authority to tax the subjects moving most of the extant gross national product, GNP, to consumption under public rule. If the «nation-state running takes over $50 \%$ GNP, we are halfway of 〈communism〉. The figure is hot: residual wealth runs private, by cooperation recipes or sunken trade forms. In its place, the nomenclatures, fittingly, organize over self-adaptive hierarchies: the «capitalism〉 vs. «communism〉 or GNP ratio to alter from 〈private〉 to 〈public〉 management, has country's officialdom, more than safe track. The no ahead way is severe query: with 〈communism〉 (Gorbachev) glasnost, the 〈private〉 economy returns, since the earlier 〈public〉 dominance aimed at self-disintegration; with 〈capitalism», split-sovereign countries make debts with potent suppliers, for amounts exceeding GNP safe ratios (out of constitutional bonds).

The flexibility in debt repayment is ambiguous help, later turned in planned abuse. The «nation-state», with 50\% GNP required by 〈public consumption and national debt equal or bigger than the GNP, is not viable; it will end in downfall, due to government's decision. The symbolic detection of safe ratios, typically, links to the 〈sovereignty〉 concept with 〈public〉 force. Steady cut-off identifies by riven-governance and divided-native/training assemblies, as if ¿independence〉 or 〈autonomy〉 is divine or ethnic mark. When such absolute reading is left out, the legality order, (Figure 9), develops in parallel, forming factual 〈public〉 relational layers, out of the 〈private〉 ones [62-67].

\section{TUTORING DUTY: INVENTION OF 〈LANGUAGE〉, FOR 〈CLAN〉 COMPREHENSION, PLANNING AND COOPERATION BUSINESS TASK: DETECTING THE (MARKET) EFFICACY AND PROFIT, FOR 〈PRIVATE〉 OPERATION MANAGEMENT LEGALITY ORDER: DISCOVERY OF THE 〈NATION STATE〉 LAYOUT, FOR THE 〈PUBLIC〉 AUTHORITY GOVERNMENT}

Figure 9: Interpersonal «symbolic` joint unearthning.

\section{Outcome Release}

The sketch, if the relational options are pivotal truths, reveals 〈natural laws〉, say, «information〉 coded within the cosmos. The readings entail monism, along racial and ethnic lines. In alternative, the total dualism refers to transcendent reality, say, sgod driven occurrences». The modern age, by explicit or implicit schemes, propose that the European countries practice split-sovereignty, sort of noteworthy achievements via competitive rivalry proficiency. The nation «closed society becomes tool, to tell how and why the success appears rewarding given peoples. Our analyses cannot trust pivotal truths: we might list singularities, carrying contingent worth: 〈life», prompting repetitions; 〈intellect», predisposing abstraction. Then, «gene evolution〉 creates the many living specie; «meme fruition〉 establishes the a posteriori 〈relational〉 framework (without a priory total truths) [68-73]. A priori godly or ethnic partitions bring to rivalry, with side belief, such as 〈Hobbs' rule».

War is natural feature, deemed to get supremacy to best-fit groups, because managing (closed societies», in which efficient hierarchies establish. Competition aims at forming top-down authority, indorsing solidarity tests, to foster the clan cohesion. The global economy falloffs mix the nations' interests: the cross-effects cannot grant the planned steering. A posteriori factual appraisals lead to steady pictures, such as 〈Kant's rule〉: the cooperation adopts altruism habits in 〈open society〉. The global ecology shows crosslinks, requiring coupled management, (Figure 10), to describe the «outcome». That result tells that the world citizen aims at global village, with bottom-up authenticity. 


\section{EXPLORATION SELF-RULE: SCIENCE CONSTRUAL VIA RIVEN AUTONOMY AND INDEPENDENT CONSISTENCY TOTAL DUALISM/MONISM: RACE PATTERNS: (SPLIT-SOVEREIGNTY) COURSE FOR (NATION STATE) FREEDOM FACTUAL DUALISM: SELF-RULING COMMUNITIES, WITH (COOPERATION) AND (ALTRUISM〉 OPPORTUNITIES}

Figure 10: From 〈pivotal truths〉, to «coupled management〉.

\section{Shared Advance}

The lose reliability of «pivotal truths〉 with godly or ethnic foundation links with the three-rank relational modes: language (to dialogue), business (to market) and law (to govern). The personal interface ripens, through education practices, towards «closed society> solidarity or «open society altruism, if we make use of the above hints. The millennium changes are clear. If global economy brings in conflictual limitation to the sovereignty fragmentation, the global ecology fully eliminates disjointed decision keeping. The thinkable growth requires global village uniform legality, (Figure 11), or the earth needs unchanging governance, maintaining unbroken protection [74-79].

\section{PROMOTION CONVERSION: 〈COOPERATION) VS. 〈ANTAGONISM〉 PLANNED BETTERMENT PROCEDURES GENE SELFISHNESS: SELF-INTEREST ENHANCED EXPLITATION OF 〈HEGEMONY〉 AND 〈COMPETITION〉 DEVICES MEME ALTRUISM: UNBROKEN PROTECTION, THROUGH (THRIFTY REMEDIAL) AND (CONTINUOUS RECOVERY)}

Figure 11: From 〈riven governance», to «common legality».

Split-sovereignty is nonsense: the «closed societies» swap into a single «open society), in which the relational construal has to work along the rational trail of the altruism, as the transparency of the ecology data tells the haughtiness of the local freedom. The resort to the «nation-state` rivalry stops. Instead of «mors tua, vita mea», all move together towards death. The altruism is thrifty remedial, when 〈sustainable corporations» act together with «certification bodies», enabling 〈big society〉 consistency. The riven governance might deal with protected economy; the global ecology shows that no marginal benefit shall distinguish to sheltered people, since no privilege can exist at the ecologic viewpoints. What we do will repeat with alike hindrances: the <altruism> does not tell that are fond of the aliens; it simply says that we avoid poisoning our existence.

\section{Altruism Cues}

The citizen of the world does not limit to closed clans; he aims at the global village, built on the «big society options, with bottom-up authenticity. The fact tells that the relational links deploy a set of effects: to enable genome-encoded plans; to resort to intellect options; to compare the on-progress results; to show decision-like talent. The 〈rationality〉 develops when the interaction level is complex: the gene selfishness does not help; the meme altruism provides hints to address ways-out and to select leads. The relational construal brings forth comparisons, judgments and choices. The meme trail tracks simulation and emulation, since the intellect options add abstract images by mimicry and copy, supporting phantasy specifications, with clearly identified merits [80-85]. The global economy is current request, when segmented markets establish. The global ecology switch in the new selflessness directions, once curtailing cognition follows. The analyses, involving the global village, address the «open society layout: we cannot deal with social or political rights, reserved to the citizens of given countries (Figure 12). The ecology requires removing the privileges, so that, at the interstate range, the civil obligations bring about full altruism compensation. The result is, perhaps, a bit too complex if the split-sovereignty persist. The question is left open, and the third relational range of the 〈legality> is, accordingly, to revise.

\section{ALTRUISM OR SELFLESSNESS: THE GENEROSITY GRANTS SAFE ON-LINE CHCKS. APPRAISALS AND PIBKS SELF-BIOLOGY: THE GENE EVOLUTION ALLOWS CURTAIILING FEASIBLE, EFFICIENT AND SELECTED OPERATIONS SELF-COGNITION: THE MEME FRUITION OFFERS IMPLEMENTING POSSIBLE, USEFUL AND APPROPRIATE CHOICES}

Figure 12: The «altruism〉 vs. «check, appraisal and pick〉. 


\section{Conclusion}

The 〈relational hypotheses〉 offer hints on different purposes. In the present survey, the central drive aims at justifying the factual interpersonal human capabilities, which establish the substance of the civilisation. The analyses suggest complex interpretations, since the images and concepts in the human minds form modify and sore-up with contingent force, but clear evidence [86,87]. Pictures and ideas have readings, in which we may directly recognise strong facts and transitions:

a) The core setups, listing formats that tell the human software/ hardware edges.

b) The critical drafts, giving details on the current economy and ecology settings.

These complex interpretations are, however, imperfect, as the core setups remain contingent, without total truth and the critical drafts are liable priority with restricted efficacy. In the survey, the absolute pictures, done by monism (and information immanence) or total dualism (and godly transcendence) have explicit mention, keeping merely figurative functions. The steady formats can enjoy right acknowledgements, e.g., trusting the formerly exemplified seven figures. At the point, the dangerous economy/ecology traits become serious confrontation, with the further epitomised five traits. The discussion on the subject, certainly, does not stop here [88-91]. The analyses need combining the steady core formats, with the looming critical defies. By now, we can move back to the 〈relational hypotheses», trying to detail the changeovers to face. The pick has separately to address the situations with explicit links to the entropy trends, either the control on saving/recovery imperatives for «sustainability», namely:

a) The swap into deteriorated surrounds and unhealthy political institutes;

b) The planned reclamation/recycling to yield ordered headway outcomes.

Formal «natural laws», with coherent structure, perhaps, identifies the core setups: the written comparisons are difficult to assess by absolute data. The second research line has just provisional worth, but the appraisals are more consistent. Can we expect programmed «sustainability> issues? The global ecology problems imply negative answers, if aimed at 〈absolute〉 construal. «Entropy〉 is fundamental truth of the cosmos' inner information: men's devised tricks to improve efficiency enhance, as well, waste and speed up decay. We may trust in 〈miracles〉: total dualism tells that degeneracy affects matter, not spirit; the man's civilization can be almighty's design. The 〈faith〉 in total truths simplifies our guesses, but we, only, relay on our invented «science), say, «knowledge», possibly, a posteriori set by the ‘falsification rule», just, allowing sprovisional〉 readings. The line does not enjoy fixed logic: the weak course, however, can explore operation dualism, once «singularities〉 occur and open peculiar options. On the earth, the 〈life〉 and the 〈intelligence〉 are odd discontinuities, bringing in proper agentive and rational wherewithal, i.e., the bases of the men's civilization.

The civil headway, built by <contingent〉 construal, is provisional or conditional upshot; its «sustainability> is not a priori certainty, but just a posteriori upshot. The outlined study offers cues on the subject, telling that 〈sustainability〉 is restricted and temporary outcome, as any other men's conceived invention. The social advance combines communication and business with political setups, in view to manage ordered localised «nation-states», each one with its govern. In the account, the parallel countries refer to their preexisting traditions, being obvious that the split-independence does need proof, if, just, the earlier autonomy exists. The «sovereignty> does not need explanations: the 〈authority and the «closed society〉 enjoy acknowledged consent. The present investigation looks at the «relational modes» affecting the men in their earth's life. The enquiry has particularly relevant outcomes, as it permits identifying really important men's traits: the language invention, the market practice and the authority instigation.

The accounts do not provide absolute proof that the three relational links necessarily develop; the provisional ties are verified hypotheses, once the language finding, the market drill and the authority urging are on duty facts, with a posteriori check. The shoc post hoc, ergo propter hoc logic cannot be used, however, the links between the three 〈relational modes〉 is stressed. In alternative, the enquiry is separately addressing the said «relational modes», as if the links shall not establish because of fit equivalence at the interpersonal rehearsal. But: idiom, barter and kerb are mind construal, with fit consistency: the current search shows details more and more meme fruition pertinent, i.e., linked to the rational deployments, after the agentive settings of the gene evolution. The earth's society organization according to suitable 〈relational> knacks, in which speech and talking or market and barter or authority and kerb are advantages for the citizens' understanding, manoeuvre and governance, is object of examinations along the study, with helpful niceties.

The details easily connect with «immanent information or with 〈godly pictures〉 if absolute data are in our availability. These are, surely, imaginary forecasts; the niceties happen being contingent facts, as the 〈relational talents characterise the humanity and enjoy provisional worth, not total truth. In the inspections, speech and talking or market and barter or authority and kerb are unbelievable brainchildren, maybe, easier to acknowledge, if 〈immanent information〉 or 〈godly pictures〉. The 〈relational〉 hypotheses, thereafter, have sketches with consistent remarks, 
but out of necessities: we do not have hints that justify idiom, trade or authority; we say these happenings build and, in parallel, the shuman cognizance〉 is awkward narration, with peculiar, induced effects [92-97]. It is hard to tell how far 〈cosmos〉 and 〈earth〉 distinguish. In the present analyses, the 〈biology〉 and the 〈cognition〉 appear strong occurrences, proposing 〈gene evolution〉 and «meme fruition», in view of «life〉 adaptation because of agentive peculiarities and intellect) completion according to rational distinctiveness.

We, perhaps, trust in laws of the nature with inner causality structure; yet: evolution is more factual: it brings the inner changes, to growth cycles and fitting editions. In like measure: fruition has truthful power: it leads the inner talent to emulation and simulation acts and to relational deployments, with rational assessments and decision-making traits. The resort to interpersonal gifts allows exploring parallel images and appraisals and balancing the crossideas or mind by-products. The mental spinoffs deal with the formation and the controlling of the 〈human knowledges, i.e., the management of our <understanding about what we discern occurring around us. We think to observe, comprehend and partake when involved in physical transformations. The collected data, acknowledged phenomena and designed actions are reliable or truthful notions, so that the shuman knowledge〉 happens duplicating the cosmos' information (in current requests). In conclusion, the 〈relational hypotheses〉 seem offering the way to bypass the access to (total truth), by factual access to truth, since the interpersonal gifts support operation alternatives.

\section{References}

1. In: Erickson JD, Messner F (Eds.)., (2007) Ecological economics of watershed management, Emerald Book. Bingley.

2. In: Norel P, Beyard P, Bergen L (Eds.)., (2010) Mondialisation et capitalisme, La découverte, Paris.

3. Ronson J (2015) So, you've been publically shamed, Riverheads Books, New York.

4. Turner A (2015) Between debt and devil: money credit and fixing global finance, Princeton Uni. Press, Princeton.

5. Versiero M (2013) Il dono della libertà e l'ambizione dei tiranni: l'arte della politica nel pensiero di Leonardo, Ist. It. Studi Filosofici, Napoli.

6. Ginsborg P (2015) Family politics: domestic life, devastation and survival 1900-1930, Yale Uni. Press, New Haven.

7. Markoff J (2015) Machines of loving grace: the quest for common ground between humans and robots, Ecco, New York.

8. O'Hagan A (2011) Julian Assange: the unauthorised autobiography, Canongate, London.

9. Putnam RD (2000) Bowling alone: the collapse and revival of American community, Simon \& Shuster, New York.

10. Smithers A (2009) Wall Street revaluated: imperfect markets and inept control, John Wiley, New York.
11. Wolferson J (2010) A global life: my journey among rich and poor, from Sydney to Wall Street to the World Bank, Public Affairs, New York.

12. Michelini RC (2010) Knowledge society engineering: a sustainable growth pledge, Nova Sci. Pub., New York, pp. 350.

13. Plender J (2015) Capitalism: money, moral and markets, Biteback, London.

14. In: Seligman EA (Edt.)., (2002) Encyclopaedia of social science, vol. XIV, MacMillan, New York.

15. Tett G (2009) Fool's gold: how the bold dream of a small tribe at J.P. Morgan was corrupted by Wall Street greed and unleashed a catastrophe, Free Press, New York.

16. Von Neumann J, Morgenstern 0 (2004) Theory of games and economic behaviour, $65^{\text {th }}$ Anniversary Ed., Princeton Uni. Press, Princeton

17. Bresciani Turoni C (2003) The economics of inflation: a study of currency depreciation in post-war Germany, Rutledge, London.

18. Miller RM (2002) Paving Wall Street: experimental economics and the quest of the perfect market, John Wiley, New York.

19. Partnoy F (2009) The match king: Ivar Kreuger, the financial genius behind a century of Wall Street, Public Affairs, New York.

20. Stiglitz JE (2001) The roaring nineties: a new history of the world's most prosperous decade, W.W. Norton \& Co., New York.

21. In: Tamm RA (Edt.)., (2011) International climate change negotiation and investment, Nova Sci., New York

22. Bingham T (2010) The rule of law, Allan Lane, London.

23. Jerven M (2015) Africa: why economists get it wrong, Zed Books, London.

24. Rodrik D (2007) One economics, many recipes: globalisation institutions, Princeton Uni., Princeton.

25. Squires J (2000) Gender in political theory, Polity, Cambridge.

26. Suhas HK (2001) From quality to virtual enterprise: an integrated approach, CRC Press, Boca Raton.

27. Tombs R (2015) The English and their history, Knopf, New York.

28. Cohan W (2011) Money \& power: how Goldman Sachs came to rule the world, Doubleday, New York.

29. Malcolm N (2015) Agent of empire: knights, corsairs, Jesuits, and spies in the late XVI-century Mediterranean world, Allen Lane, London.

30. Michelini RC (2008) Knowledge entrepreneurship and sustainable growth, Nova Sci. Pub., New York pp. 325.

31. Myerson G (2001) Heidegger, Habermas and the mobile phone, Icon Books, Cambridge.

32. Russell G (2014) Heirs of forgotten kingdoms: journey into the disappearing religions of the Middle East, Basic Books, New York.

33. Farrll Ge (2011) Crash of titans, greed, hubris the fall of Merrill Lynch, Crown Business, New York.

34. Henriques D (2001) The wizard of lies: Bernie Madoff and the death of trust, Times Books, New York.

35. In: Melli M, Cacciotti A (Eds.)., (2011) Francescani e uso del danaro, EBF, Milano.

36. Morris J, Carey D (2010) King of capital: the remarkable rise, fall and rise again of Blackstone and Steve Schwarzman, Crown Business, New York. 
37. Powell G (2006) Beginning database design, J. Wiley, Indianapolis.

38. Shehadeh R (2010) A rift in time: travels with my Ottoman uncle, Profile, London.

39. Goodwin R (2015) Spain: the center of the world 1519-1682, Bloomsbury, London.

40. Kelly S (2010) Scott-land: the man who invented a nation, Polygon, Edinburg.

41. Meyer M (2009) The Berlin wall: my part in its downfall, Arcadia London.

42. Sheldrick D (2012) Love, life \& elephants: an African love story, Viking, London.

43. Smolin L (2013) Time reborn: from the crisis of physics to the future of the universe, Allen Lane, London.

44. Atwater PMH (2011) Near-death experiences, MJF Books. New York.

45. Jnsam H, Franke Wittle I, Goberna M (2009) Microbes at work, Springer, London.

46. In: Pastorok RA, Bartel SM, Ferson S, Ginzburg LR, (Eds)., (2001) Ecologic modelling in risk assessment: chemical effects on populations and ecosystems, CRC Press, Boca Raton.

47. Riley WF, Sturges LD, Morris DH (2006) Mechanics of materials, J. Wiley, Chichester-New York.

48. Service T (2012) Music as alchemy: journeys with great conductors and their orchestras, Faber \& Faber, London.

49. Woodward B (2002) Bush at war, Simon \& Schuster, New York.

50. Lamarque P (2010) The philosophy of literature, Blackwell, Oxford.

51. Michelini RC (2009) Robot-age knowledge changeover, Nova Sci. Pub. New York, pp. 344.

52. Nightingale C (2012) Segregation: a global history of divided cities, Uni. of Chicago Press. Cicago.

53. Putman RJ (1994) Community ecology, Chapman and Hall, London.

54. Sauret MJ, Gori R, Abelhauser A (2011) La folie évaluation: les nouvelles fabriquées de la servitude, Mille et une nuits, Paris.

55. In: Stiglitz JE (Edt.)., (2002) Can anyone hear us? Crying out for change from many lands, World Bank Reports, Washington.

56. Eichengreen B (2015) Hall of mirrors: great depression and great recession, and the uses/misuses of history, Oxford Uni. Press, New York.

57. Naef S (2012) La questione dell'immagine nell'Islam, Obarrao, Milano.

58. Plokyi S (2015) The gates of Europe: a history of Ukraine, Allen Lane, London.

59. Stahel WR, Børlin M (1987) Stratégie économique de la durabilité, Soc. de Banque Suisse, Genève.

60. Wrangham R (2009) Catching fire: how cooking made us human, Basic Book, New York.

61. Zajonc A (1993) Catching the light: the entwined history of light and mind. Bantam Books, New York.

62. Close F (2012) The infinity puzzle: quantum field theory and the hunt for an orderly universe. Basic Book, New York

63. Easterly W (2001) The elusive quest for growth: the economists' adventures and misadventures, MIT Press, Cambridge.

64. Lincoln D (2012) Understanding the universe: from quarks to the cosmos, World Sci. Books, London.
65. Michelini RC (2016) Cognitive revolution quest: human civilisation prospects, ARACNE, pp. 357.

66. Odum HT (1971) Environment, power and society. Wiley Interscience, New York.

67. Suh NP (1990) The principle of design. Oxford Uni. Press, New York.

68. Cox B, Forshow J (2012) The quantum universe: everything that can happen does happen, Capo Press, New York.

69. Friedman TL (2009) Hot, flat and crowded: why we need a green revolution and how it can renew America, Farrar, Straus \& Giroux, New York.

70. Keane JN (2001) Public life and late capitalism towards a socialist theory. Cambridge Uni. Press, Cambridge.

71. Sorrentino F, Pettenati MC (2014) Orizzonti di conoscenza, Firenze Uni. Press, Firenze.

72. Tononi G, Edelman G (2000) A universe of consciousness: how matter becomes imagination. Basic Books, New York.

73. Young M (2010) The ghosts of martyrs square: an eyewitness account of Lebanon's life struggle. Simon \& Schuster, New York.

74. In: Clark A (Edt.)., (2008) Super-sizing the mind: embodiment, action and cognitive extension, Oxford Uni. Press, New York.

75. Kotlikoff LJ (2010) Jimmy Stewart is dead: ending the world's on-going financial plague with limited purpose banking, John Wiley \& Sons, Hoboken, pp. 272.

76. Michelini RC (2012) Society progress evolution: sustainability and responsiveness, Nova Sci. Pub., New York, pp. 418.

77. Nye J (2015) Is the America century over? Polity Press, Cambridge.

78. In: Pridgen TS, Drury EK (Eds.)., (2010) Handbook on environmental quality, Nova Sci., New York.

79. Starr K (2009) Golden dreams: California in the age of abundance 19501963, Oxford Uni. Press, Oxford.

80. Green B (2012) The hidden reality: parallel universes and the deep laws of the cosmos, Penguin Books, London.

81. Hastings M (2012) All hell let loose: the world at war 1939-1945, Harper Press, London.

82. Parker M (2011) The sugar barons: family, corruption, empire and war in the West India, Walker \& Co., New York.

83. Sauser B, Boardman J (2008) Systems thinking, CRC Books, Boca Raton.

84. Stern JM, Ross I (2003) Against the grain: how to succeed in business by peddling heresy, John Wiley, New York.

85. Zaccaria G (2012) La comprensione del diritto, Laterza, Bari.

86. Mee N (2012) Higgs force: a symmetry-breaking force that makes the world an interesting place, Lutterforth Press, London.

87. Paul R (2009) End the Fed, Grand Central, New York.

88. Pandya S (2013) Muslim women and Islamic resurgence: religion, education and identity politics in Bahrain. Tauris, London.

89. In: Shaw J, MacKinnon D, Dochterty I (Eds.)., (2008) Diverging mobility? Devolution, transport and policy, Emerald Book, Bingley.

90. Simpson JA, Weiner ESC (2000) Oxford dictionary of historical principles. Clarendon Press, Oxford.

91. West Eberhard MJ (2003) Developmental plasticity and evolution, Oxford Uni. Press, Oxford. 
92. Rogan E (201) The fall of the Ottomans: the great war in the Middle East, Allen Lane, London.

93. Sebestyen V (2015) 1946: making the modern world, Macmillan, London.

94. Strang H (2002) Repair or revenge: victims and restorative justice, Clarendon Press, Oxford.

\section{ISSN: 2574-1241}

DOI: 10.26717/BJSTR.2021.40.006403

Rinaldo C Michelini Di San Martino. Biomed J Sci \& Tech Res

(C) (P) This work is licensed under Creative

Submission Link: https://biomedres.us/submit-manuscript.php
95. Uchitelle L (2006) The disposable America: layoffs and their consequences. Knopf, New York.

96. Versiero M (2013) Il dono della libertà e l'ambizione dei tiranni: l'arte della politica nel pensiero di Leonardo, Ist. It. Studi Filosofici, Napoli.

97. Warrick J (2011) The triple agent: the Al-Qaeda mole who infiltrated the CIA, Doubleday, New York.

$\begin{array}{ll}\text { BIOMEDICAL } & \text { Assets of Publishing with us } \\ \text { RESEARCHES } & \text { - Global archiving of articles } \\ \text { - Immediate, unrestricted online access }\end{array}$

